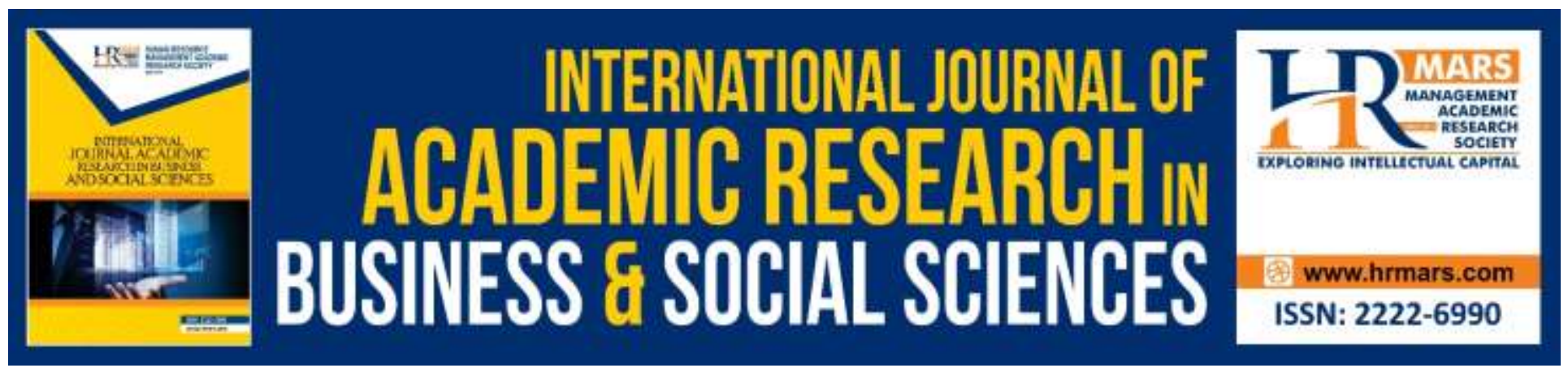

\title{
Strategies to Close the Knowledge Gap of New Engineers in the Automotive Industry in Malaysia
}

\author{
Yuen Fook Chan, Selvam Balaraman
}

To Link this Article: http://dx.doi.org/10.6007/IJARBSS/v9-i13/6474

DOI: 10.6007/IJARBSS/v9-i13/6474

Received: 02 August 2019, Revised: 28 August 2019, Accepted: 04 September 2019

Published Online: 23 September 2019

In-Text Citation: (Chan \& Balaraman, 2019)

To Cite this Article: Chan, Y. F., \& Balaraman, S. (2019). Strategies to Close the Knowledge Gap of New Engineers in the Automotive Industry in Malaysia. International Journal of Academic Research in Business and Social Sciences, 9(13), 270-283.

Copyright: (C) 2019 The Author(s)

Published by Human Resource Management Academic Research Society (www.hrmars.com)

This article is published under the Creative Commons Attribution (CC BY 4.0) license. Anyone may reproduce, distribute, translate and create derivative works of this article (for both commercial and non-commercial purposes), subject to full attribution to the original publication and authors. The full terms of this license may be seen

at: http://creativecommons.org/licences/by/4.0/legalcode

Special Issue: Revolutionizing Education: Challenges, Innovation, Collaboration, 2019, Pg. 270 - 283 http://hrmars.com/index.php/pages/detail/IJARBSS

JOURNAL HOMEPAGE

Full Terms \& Conditions of access and use can be found at http://hrmars.com/index.php/pages/detail/publication-ethics 


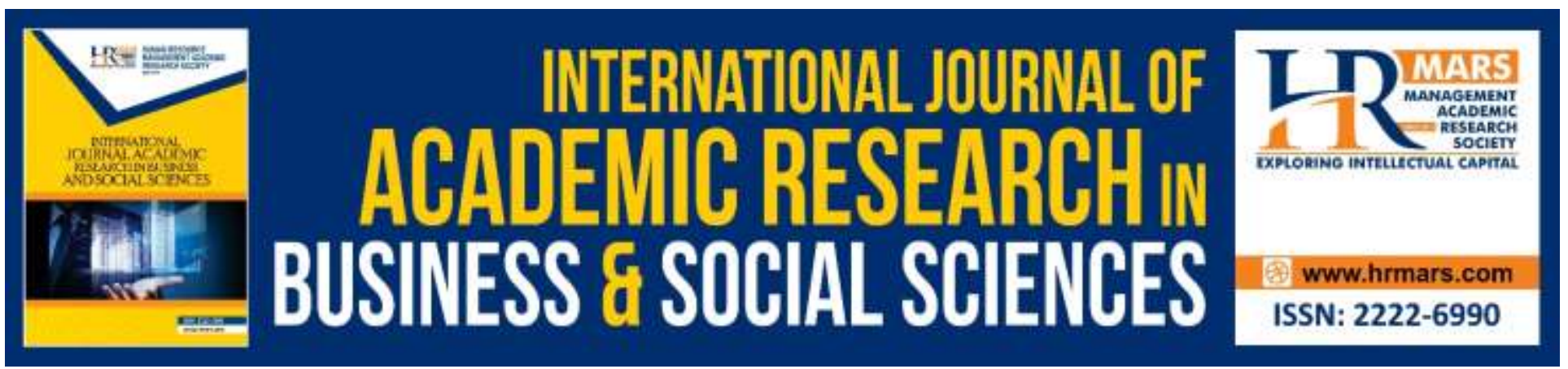

\title{
Strategies to Close the Knowledge Gap of New Engineers in the Automotive Industry in Malaysia
}

\author{
Yuen Fook Chan ${ }^{1}$, Selvam Balaraman ${ }^{2}$ \\ ${ }^{1}$ Faculty of Education, Universiti Teknologi MARA, 42300 Puncak Alam, Selangor, Malaysia \\ ${ }^{2}$ Asia e-University, 50000 Kuala Lumpur, Malaysia
}

\begin{abstract}
According to Marimuthu and Ismail (2009), "Human capital refers to processes that relate to training, education and other professional initiatives in order to increase the levels of knowledge, skills, abilities, values, and social assets". In today's global economy, a nation's success is depending fundamentally on the knowledge, skills and competencies of its people. Education systems are designed and implemented to equip students with knowledge and skills that will help them succeed in their chosen profession in life. Hence, this study aims to identify strategies to close the knowledge gap of new engineers in the automotive industry in the country. The scope of this research is confined to the theories of Human Capital, which relate to the capabilities and skills of an employee in improving job performance. A qualitative case study method was employed for the analysis and comparison of data from public and private universities and the automotive manufacturing industry in Malaysia. The informants involved in this study included one human resource manager, two manufacturing supervisors, six new engineers and four lecturers. Based on the findings, this study has recommended various strategies for different groups of stakeholders to close the knowledge gap of new engineers in the automotive industry. Keywords: Strategies, Knowledge Gap, New Engineers, Automotive Industry
\end{abstract}

Introduction

According to Muneer \& Amilin (2014), ever since the first national car, the Proton Saga, rolled out of its plant in 1985, Malaysia has obtained much recognition regionally and internationally for its outstanding achievements in the automobile industry. The chain of opportunities created by the automobile industry has proven to be a major contributor to the economy of Malaysia, as the automotive sector has gone through several phases of development over a long period of time.

In fact, Malaysia has started initially in 1950s with the assembling of passenger and commercial vehicles. This was done in order to capitalize on the reduced import tax for locally assembled vehicles compared to the higher import tax for importing complete built vehicles from other countries, while providing more employment opportunities for the locals (Muneer \& Amilin, 
2014). Additionally, the change of government policy in the 1980 s to build an advanced nation by indulging in heavy industrialization has paved the way to put more emphasis on the manufacturing sector. One of the major beneficiaries of the policy was the automotive industry which has had a chain of benefits in the evolvement of many other small industries that produce auto parts and components. The automotive industry is classified into two sectors: 1) manufacturing, and 2) assembling operations of motor vehicles. To date, there are four automobile manufacturers, nine assemblers, three composite body sports car makers, 23 franchise holders having the right to assemble various models of passenger and commercial vehicles, nine motorcycles manufacturers or assemblers, and 350 component manufacturers (MIDA, 2010). The four major national auto manufacturers are PROTON, PERODUA, INOKOM and MTB (Malaysian Trucks and Buses), whereas the remaining auto players are considered assemblers.

Undeniably, the implementation of ASEAN Free Trade Area (AFTA) had posed some degree of challenges on local automotive industries to be more competitive to survive in the region. Furthermore, the entrance of Thailand and Indonesia into the automotive industry has been a major threat for local automotive players. They have to look forward to maintain quality, efficiency, productivity and most of all, the country's policy on automotive investors to expand their investment and business. In order to survive the tough competition, local industries have to focus on factors such as cost, customer, and process and the most critical factor, the recruitment of a capable workforce at all levels (MIDA, 2010).

\section{Literature Review}

Jose, Blanca \& Maria-del (2012) stated that in focusing on the occupational competence of engineering graduates, the relationship between the capacity of a graduate and the demands of a certain situation or task must be balanced. The job competency needed might include knowledge and intellectual skills as well as non-cognitive factors such as motivation or self-confidence. The fact that competences can be viewed from various angles must be considered (Jose et al., 2012). On the offering side, we should consider: formal competence, which can be defined as the amount of time used up for educational activities and training, and actual competence - the result of formal education and individual professional and day-to-day experiences. In contrast, from the demand side, we should also consider the official need for competence that corresponds ideally to the real competence prerequisites of a specific job, and the actual competence needed by the specific job that could be affected by the need for qualified employees, balance of supply or the dearth of a profound analysis of the job.

In fact, the importance of learning at the workplace is confirmed with the concept of the 'learning organisation'; and other concepts such as 'lifelong learning' and the 'learning society' are also part of 'workplace learning'. Workplace learning is considered beneficial for both employers and employees as it promises improvements in employee performance and productivity and creates opportunities for personal development. This will subsequently give job satisfaction and selffulfilment as there would be better jobs and more skilled and knowledgeable employees to occupy them (Malloch, Cairns, Evan \& O' Connor, 2010). The workplace has become a place of learning with two different purposes: the first is the improvement of the organisation in the area of production, effectiveness and innovation, and the second is the improvement of individuals in the area of knowledge and skills. Workplace learning depends on the degree to which 'learning' and 'work' are 
separated. The workplace as a place for learning is known to have three broad approaches: the workplace as a site for learning, the workplace as a learning environment, and that learning and working are inextricably linked.

The first approach is that learning is separated from work, where learning activities take place in the form of in-house training, or off-the-job training takes place outside of the working environment. In the second approach, learning takes place at an employee's workplace and is known as 'on-the-job training'. The third approach is known as 'continuous learning' and asserts that 'learning is the new form of labour' (Malloch et al., 2010). In this approach, the learning takes place in the manner that the workplace is designed to intensify processes of learning, where employees become learners and learn skills that are relevant to their own jobs. In this approach, the learning occurs 'informally' through team activity, problem solving and communication with colleagues and clients. These fields are similarly mentioned by Levenberg and Caspi (2010) as Informal learning which is not supported by an educational or training institution. It is controlled primarily by the learner, normally it does not have a predefined structured curriculum, and does not result in receiving a certificate. Informal learning can also be achieved through every-day or social activities, although the learner needs to consciously recognize, even if in retrospect, that he was involved in learning.

Findings by Hairuzila, Hazadiah \& Normah (2014) show that it is a generally accepted notion that certain non-technical competencies such as problem analysis and solving, communicative skills, team work and cooperation among employees play a pivotal role in the professional development of an engineering graduate. In fact, Nabila and Normah (2012) also found that industry has shown a keen interest in practical programs for undergraduate students as a means to provide students work experience that might facilitate the development of their competence.

Furthermore, according to Chan and Lee (2012), those who graduated without profound communication skills have now come to realize the value of those skills and are of the opinion that Technical Communication instruction (which includes the ability to write reports) has to be made compulsory in an undergraduate engineering course. A competent engineer should possess the skills to give clients a clear and succinct explanation on even specialist subjects. Based on the study by Chan and Lee (2012), the industrial sectors gave top priority to effective communication for engineers and the community at large, and the ability to execute problem identification, formulation and solution when looking for a better engineering workforce. This finding is a proof of mounting evidence that employers, particularly those who have joined or are joining the quality revolution, need people who are capable of fitting into a team-centred work attitude where professionalism, interpersonal skills and communication are as essential as technical skills, without having to learn them on the job.

However, in a presentation by the Malaysian Employees Federation (MEF), it was reported that there is an oversupply of inexperienced and young graduates which are not demanded much by private companies (Chan \& Lee, 2012; Hazmilah, 2008). In reality, companies are increasingly in need of technical and science graduates who have also acquired people skills but the current crop of such graduates does not meet the needs of the industry. As a result, skill deficiencies and gaps impact engineering companies in many ways: including promotion of new products to the market, operational costs, business development, and capability to fulfil customer demands, quality and service objectives. If the skills gap is not narrowed down, there would also be negative consequences 
INTERNATIONAL JOURNAL OF ACADEMIC RESEARCH IN BUSINESS AND SOCIAL SCIENCES

Vol. 9, No. 13, Special Issue: Revolutionizing Education: Challenges, Innovation, Collaboration., 2019, E-ISSN: 2222-6990 @ 2019 HRMARS

in business opportunities for engineering employers in a global market that is highly competitive. In a nutshell, the skills gap that exists in the working world has to be resolved.

\section{Method}

This research utilised a case study method to collect data from two private universities, two public universities and an automotive manufacturing company. The automotive manufacturing company selected is located in the state of Selangor. It is a Malaysian and Japanese joint venture which was established in 1970 and has been producing non-national cars for the local and foreign market. The interview data were collected from six new engineers (NE1 to NE6), one human resource manager (HRm) and two supervisors (SV1 to SV2), and four lecturers (LEC1 to LEC4) who are working or have worked in the relevant automotive industry. These informants were expected to appropriately respond to questions pertaining to identifying the strategies to close the knowledge gap of new engineers at the workplace from their varying perspectives. Semi structured open-ended interview questions were selected to document face to face interview findings from these participants.

Open coding was used to identify concepts and properties through comparative analysis to discover, and categorise the variables according to their similarities and differences based on the themes which emerged from the analysis. The coding of the qualitative data has allowed the coding of themes to emerge inductively by breaking down the data into bits of information and then using axial coding to put the pieces of information together again in a meaningful way to describe what is happening with each interviewee. When central ideas begin to emerge from the data, these ideas are represented as categories to describe the variables voiced out by each respondent. The categories are bits of information from each interview that were grouped to explain the specific characteristics under each theme. Categories or themes that captured recurring patterns in the data have been constructed through the constant comparative method of data analysis in this qualitative study.

\section{Findings and Discussion}

The qualitative data have been classified into four sub-themes after the analysis. All these sub-themes are related to the major theme of "developing strategies to close the knowledge gap among new engineers in the automotive industry". The qualitative data obtained were then linked to relevant literature and past studies in this section to provide meaningful interpretation in Malaysian context.

\section{Cooperation among the Stakeholders}

According to HRm all stake holders, namely the university, industry, students and education department or ministry, should meet to discuss the readiness of students to work in the industry. This communication needs to take place frequently so that the changes in technology and policies can be updated. The education department/ministry should play a major role in initiating committees that comprises all involved parties and find ways to organise regular meetings. Similarly, LEC2 has suggested that: "University should tie-up with more industries to know the requirements and analyse them to create courses that are suitable for students. Feedback from these companies can be used to identify some core knowledge and skills required by industry. It was concurred by LEC3 that: "Industry must be engaged in deciding university syllabus. Everybody must take responsibility in creating competent engineers rather than pointing fingers" (LEC3). The same opinion is shared by 
NE2, that, there should be good communication among all the stakeholders. "University should talk to industry often to understand the changes in technology and skills needed to customise the syllabus" (NE2). It was agreed by LEC1 that:

"Lecturers need to take the initiative and organize visits to the industry and study on the needs of industry in terms of requirements of new graduates' competencies. We are producing students for the industry; as such we have to know what the expectations of the industry are. We can also study and analyse the requirements and the suitability of the skills and knowledge students acquire from university".

Hence, informant LEC1 suggested inviting industry experts to be part of the university education team and build a University-Industry relationship. Industry experts can give their input through talks and also conduct some manufacturing-based courses. Such involvement will benefit the students and also lecturers to understand the culture in the industry. Some kinds of incentive must be offered to attract the industry experts to participate in university activities. On that note, the opinion of SV1 was that:

"University should prepare engineers for industry and not focus only to pass examination. Paper qualification alone is insufficient for engineers to grow further in their career. Higher academic grades would make them knowledgeable in principle but devoid of 'hands-on' experience which is most important in a manufacturing environment in order to withstand work related pressure".

However, SV2 suggested that, university should also talk to new engineers to identify the skills needed to be included in the university syllabus. New engineers should be able to give accurate feedback to university as they are the connecting point for the university and industry.

"I will not be able to advise the university as I don't know what is happening there and university curriculum developers are not in the industry to know what is happening here. As such the new engineers would be the right person for universities to talk to as alumni or in tracer study in order to solve the minor issues bothering both the university and industry" (SV2).

It is essential and timely for all stake holders to help new graduates to be prepared to face the challenges at industry. According to Angelina Seow, Chong \& Kendall (2015), the enhancement plan of strategic university-industry engagement has been launched to urge universities to collaborate with industry to enhance their curriculum and encourage lecturer placement in industry. In the past, Salleh and Omar (2012) found that companies that collaborate with universities typically have higher productivity rates than companies that do not have such collaboration. Hence, in the Tenth Malaysian Plan (2011-2015), the government has emphasized on strengthening industry and research collaboration as well as focusing on the industrial attachments that can help fresh graduates to meet the evolving requirements of industry (EPU, 2010). Obviously, the objective of university and industry 
INTERNATIONAL JOURNAL OF ACADEMIC RESEARCH IN BUSINESS AND SOCIAL SCIENCES

Vol. 9, No. 13, Special Issue: Revolutionizing Education: Challenges, Innovation, Collaboration., 2019, E-ISSN: 2222-6990 @ 2019 HRMARS

collaboration is to enhance academic programs to ascertain that the curricula are current, relevant and in line with the demands of the workplace.

\section{Relevant Courses in University Curriculum}

It was also agreed by HRm that lecturers must have good industry exposure and keep updating themselves on the latest development in industry. Lecturers should make more visits to industry and understand the industry's requirements in order to train the students appropriately. "If a lecturer is passionate enough in educating students, he will be interested to observe the production process and identify the important knowledge and skills required for students" (HRm). It was concurred by NE4 that:

"University should teach courses that are relevant to manufacturing in order to equip the students with relevant skills and knowledge. University should inform the students on the importance of the courses offered and how this knowledge could help them in future in the industry".

It was agreed by NE5 that, there should be a balance between engineering knowledge and industry competency requirement.

"University should design all their programs to be $50 \%$ industry related and $50 \%$ engineering knowledge-based curriculum. This would give a fair choice for the students to select their work environment as pure engineering, manufacturing or other related sectors".

On the other hand, the informant NE1 suggested that engineering students must be exposed to more of hands on practical training rather than theoretical lessons which can be useful at work in any manufacturing industry:

"University should provide more practical training rather than theory as students will remember practical training much easier than theory lessons. When theory is supported with practical work it will be more meaningful and ...easy to understand the concept" (NE1).

It was suggested by a LEC2 that:

"Students must be prepared to face the challenges of industry. Industry is a serious business environment unlike the university which is a learning place. Students must be able to accept this fact and transform immediately once they graduate from the university".

Both the new engineer (NE1) and lecturer (LEC2) have suggested that university should provide more practical training rather than theory as students will remember practical training much easier than theoretical knowledge. When theoretical knowledge is supported with practical 
knowledge, it will be more meaningful and easier to understand the concept. Hands on experience is always good, and therefore any type of practical experience would be highly beneficial to all students entering the manufacturing sector. As pointed out by Nabila and Normah (2012), the main concerns of the academic staff relating to the subject they taught are lack of practical skills and the inability to give exposure to new technology implied in industry nowadays. Sufficient equipment and facilities must be there to expose the students to the processes related to the real industry and it will assist the students in terms of gaining hands on experience. Employees with a blend of sound practical and theoretical engineering knowledge along with humanistic skills are recognized and valued by employers.

Similarly, as stated in the past findings by Zaliza and Safarin (2014), "today excellent academic results do not guarantee Malaysian graduates a job". As such, universities should review their curriculum to be more practical based so that students will be able to develop the ability to work in various industries. A blend of these skills and knowledge into the engineering curriculum would enable students to refine and develop professional skills. Subsequently, students will be better prepared to face the challenges in industry and be adequately competent to handle given tasks quickly in their early professional careers. Thus, it is essential for lecturers to have sufficient hands on experience, because as stated by Kartina (2015), experiential learning is feasible if the university lecturers have exposure to industrial experience as engineers and the students have a certain level of fundamental knowledge to maximize the learning process. Hence, Tang (2014) has emphasised that experienced instructors will pass down to students not only their intellectual understandings of professional work, but also the attitudes and emotions deemed proper for the profession.

This finding is concurred with Tang (2014)'s study which emphasised that "some engineering faculty in Picker also make efforts to create course content relevant to students' experiences and expectations. Such efforts will definitely enhance students' intellectual and moral sophistication. As highlighted by Chan, Aziz \& Yohan (2013), "In an academic environment, educational providers cannot educate students in isolation. Unsuitable curriculum won't be able to prepare students with state-of- the-art skills and knowledge". New engineers must not only have good knowledge on engineering, but other skills such as human management and communication skills which are also essential to survive in industry. However, as concurred with the past findings by Tang (2014), "for many students and some faculty in the case studies, the goal of integrating the liberal arts has too often emphasized the refinement of students' professional skills-communication, teamwork, information literacy, project management, etc. - at the expense of more extensive intellectual goals".

Besides that, Kaushal (2016) pointed out that most of the engineering college students only study one day before the examination. This might be in part due to the emphasis on test scores rather than learning. Therefore, the engineering curriculum should be reviewed to enable students to think creatively, generate new ideas and adapt to new environments rather than memorising for the purpose of passing examinations. Students should be initiated into the awareness of these skills and their significance and be encouraged to conduct self-analysis to identify their strengths and specific attributes which will facilitate goal setting. Subsequently, once the clarity of strengths and attributes has been achieved, students should acquire these skills by maximizing participation in activities and courses that endorse these skills. This entire exercise will change the present scenario, in which we are training a mass of students without any specific attributes to make a mark in the industry (Kaushal, 2016). Education should be able to focus on the development of the whole person. The 
INTERNATIONAL JOURNAL OF ACADEMIC RESEARCH IN BUSINESS AND SOCIAL SCIENCES

Vol. 9, No. 13, Special Issue: Revolutionizing Education: Challenges, Innovation, Collaboration., 2019, E-ISSN: 2222-6990 @ 2019 HRMARS

review of the engineering curriculum for the benefit of potential engineers may not necessarily be at the expense of quality of pure engineering courses.

\section{On-the-Job Training and Internship Program}

As agreed by LEC3, industry must understand that every individual is different in nature and has to be screened objectively during selection of the candidate. Relevant training must be provided before assigning them to work. There will always be issues with new engineers and time must be given for them to adapt to the industry environment. It was suggested by NE4 that: "Industry must find out the needs of new engineers through a proper 'training need analysis' or 'competency needs analysis' in order to provide specific training programs". It was concurred by NE2 that: "Industry must analyse engineers' problems in terms of strengths and weaknesses and provide training to improve and capitalise on their strengths as every new engineer's problems are not the same". Along this line of discussion, there was a suggestion by NE5 that: "Industry must make training compulsory for all staff; otherwise there will always be tendencies to give excuses for not attending training". Sharing on the opinion, NE1 added that:

"Industry should allocate sufficient time for new engineers to be trained on the job and provide formal training. Most of the time we miss training due to busy work schedules. Training provided for new engineers must also be relevant and designed according to the needs".

It was concurred by NE6 that:

"Industry's first preference must be human development. It is said that workers are the most important asset of an organization but in reality, it does not seem so. It should not only be the vision of an organisation, but it must be reflected in their practice".

A different opinion was given by LEC4:

"Industry must know the kind of education provided to students in university and provide the necessary training at industry to close the gap. It is not possible for university to meet all specific industry requirements" (LEC4).

It was commented by SV2 that the new engineers are depending on their immediate superior to learn on the job. Hence, supervisors must be well trained and qualified to coach their subordinates.

"I have attended coaching skills training at my industry but I need more time to practise and become good at coaching. Coaching is only a part of my job as I have my own tasks to be completed. I have to manage many other duties and find time to coach my subordinates" (SV2). 
On this matter, the industry also has its role to play. According to NE3:

"Industry should select the potential students to be employed and guide them from 3rd year onwards. This can be done in collaboration with the university and provide an opportunity for the industry to inform the students on the needs".

The above statement was echoed by LEC1 that: "Industry can pre-select their preferred candidates to be employed from third year students in a four-year program and let them know the requirements or guide them while they are in university. They may sponsor the students from third year onwards and bind them with a contract to join them after completion of university education".

Hence, informant NE6 was suggesting that university should have a well-planned internship program for all students.

"Internship programs should be considered seriously with a proper plan on what should be the outcome at the end of the training. Failure to do this may end up in doing unrelated work during internship for the sake of fulfilling the criteria of completing industrial training only. More industry related projects for final year would give good hands on experience for students" (NE6).

On the other hand, the suggestion given by LEC2 is that:

"Industry should plan to do part of their research and development at university. Common R\&D facilities can be set up at university on a shared cost for mutual gain. However, some kind of policy must be in place to gain trust. Lecturers should also be exposed and gain knowledge and experience that subsequently can be benefitted by students".

There was also a suggestion by SV1 that special interim training should be provided for new engineers immediately after completing university education and right before joining any organization. This would save the time spent for training them at industry on simple generic manufacturing skills and knowledge. Industry can focus on developing them on specific technical training.

"There are institutes like 'Malaysian Automotive Institute' (MAI) under the Ministry of International Trade and Industry (MITI) that provide such trainings for fresh graduates. More institutes like MAl should be there to provide interim training for fresh graduates" (SV1).

There are some issues pointed out by Ferreira and Abbad (2013) that ; despite their importance, research shows that training needs analysis (TNA) has not been done in a systematic manner in organizational settings. It seems that training needs analysis and research still have an almost exclusively diagnostic/procedural and reactive focus, concerned only with how to do it in the 
present. Any training programs devised without following the proper method of the TNA process will end up in training programs having minimal contribution towards meeting the organizational goals.

Besides that, internship programs should be considered seriously with a proper plan on what should be the outcome at the end of the training. Failure to do so may end up in doing unrelated work during internship for the purpose of fulfilling the criteria of completing industrial training only. Concurred by past findings by Lim, Nor Idayu, Basri, Norhanim \& Hamimi. (2016), there seems to be a blunder between expectations of companies and students. Students expect to be given the training during their placement, whereas companies expect students to be well equipped with the knowledge and hands-on skills acquired in the university before starting their internship (Lim et al., 2016). If universities hope to enhance the educational experiences and the learning that occurs in internships, setting goals and objectives for internships is critical. Additionally, the goals and objectives should be clearly explained to the potential interns as well as the worksite supervisors. It is only when all parties begin with the same vision that the goals and objectives will become effective learning tools. There must be a strong aspiration and commitment at university and faculty level for an effective and meaningful internship. An effective internship will help university to achieve its goal and Interns to acquire the work-related skills. The internship should be flexible and modified to the needs of both the student and the host organization and it should be planned in a way so that the student is given the chance to narrow the gap between theory and practice (Laguador, 2013).

\section{Changing the Mind-Set of New Engineers}

LEC1 suggested that students must take the initiative and be keen to understand industry requirements. Students must search for some information about the industry before they are going to attend an interview. Prior knowledge on the company's information would enable them to be impressive in the interview. It was agreed by LEC4 that:

"Students must be able to change their attitude and mind-set. They cannot have the same attitude as student, industry is a place to earn a living and are business oriented, not a place for learning alone".

\section{LEC4 further elaborated that:}

"Engineering education should be designed in such a way to train students on certain skills such as creativity and critical thinking. These skills are generic in nature and essential for students to tackle any work-related problems. To solve work related problems, students need to use their common sense and creative thinking skills".

As stated by Abdul Ghani (2013) that most of the lecturers indicate that the current graduates are not fully equipped with the necessary soft skills to survive in the working fields. In fact, they need to learn communication and interpersonal skills necessary to adapt to a new job and for successful job performance, and they need to become acclimated to the organization and its employees if they want to put themselves on a successful career path. Besides that, students also need to make use of their common sense and creative thinking skills that they have developed during university days to 
solve work related problems. As emphasised by the past findings of Rahmah, Ishak \& Lai (2011), "the definition of expected work skills is not only academic and technical skills, but includes a range of attitudes and habits to secure employment and grow within the organization". The graduates' attitude and human capital variables such as education, training and experience, will affect their ability and opportunity to meet labour market requirements.

\section{Conclusion}

From this analysis we can conclude that there is still a lack of communication between all the stakeholders. University must tie-up with more industries to understand the issue of the knowledge gap among the new engineers. There is still a lack of mutual support from both the university and industry to guide the students precisely. Lecturers can guide students correctly if they make more visits to industry to gain experience and understand the prevailing culture at industry. Universities should include more manufacturing courses and hands on training as there are more vacancies available for engineers in the manufacturing industry. The internship program must be designed, executed and monitored holistically to ensure the effectiveness. Students must be well informed of the work culture and the competency expectations at industry rather than focusing on passing examination at university. Students must strive to change their attitude and be prepared to get into the working world. Students must also take their own initiative to learn about industry requirements and be well prepared for interview sessions. There must be a proper training needs analysis done and training must be made compulsory and done in a timely manner to help the new engineers to be competent at work. The superiors must be trained well to be competent coaches and guide the new engineers appropriately. Nevertheless, industries can sponsor potential students from early stages in university to guide them well before being employed and more industry projects to be done in the final year at university.

\section{Acknowledgements}

This paper is funded by the Trust Fund of the Faculty of Education, Universiti Teknologi MARA, Malaysia.

\section{References}

Abdullah, A. G. K. (2013). Bridging the gap between industry and higher education demands on electronic graduates' competencies. Journal of Electrical and Electronics Engineering, Volume 8, Issue 1.

Seow, A. V. Y., Chong, A. K., \& Kendall, G. (2015). Managing university-industry collaborations in Malaysia by examining its critical success factors: a dyadic approach. World Review of Business Research, Vol. 5, No. 3. September 2015 Issue. Pp. 213 - 230.

Chan, Z. H., \& Lee, C. P. (2012). Professional competency and the young engineer: Bridging the gap. Jurutera April 2012. Young Engineers Section, IEM.

EPU (2010). Tenth Malaysian Plan 2011-2015. Retrieved from http://onlineapps.epu.gov.my/rmke10/rmke10_english.html

Ferreira R. R. \& Abbad, G. (2013). Training needs assessment: Where we are and where we should go. BAR, Rio de Janeiro, v. 10, n. 1, art. 5, pp. 77-99.

Hairuzila, I., Hazadiah, M. D., \& Normah, A. (2014). Integrating Soft skills in the 
INTERNATIONAL JOURNAL OF ACADEMIC RESEARCH IN BUSINESS AND SOCIAL SCIENCES

Vol. 9, No. 13, Special Issue: Revolutionizing Education: Challenges, Innovation, Collaboration., 2019, E-ISSN: 2222-6990 @ 2019 HRMARS

teaching of hard sciences at a private university: A preliminary study. Pertanika Journal Social Sciences \& Humanities, 22(S): $17-32$.

Hazmilah, H. (2008). Exploring engineering employability competencies through interpersonal and enterprise Skills. Coventry University.

Chan, H., Aziz, A. L., \& Yohan, K. (2013). Exploration of the gap between business management curriculum and employability requirements: A study of curriculum designers and recruiters' perceptions. University Malaysia Kelantan.

Jose A. G., Blanca M. M. \& Maria-del V. S. O. (2012). Congruence between non-technical market required competences and competences met by new engineering programmes. The case of Spain. 4th International Symposium for Engineering Education, 2012. The University of Sheffield. UK.

Kartina, J. (2015). Perception of students towards lecturers teaching engineering courses with industry experience: A case study in Malaysia Technical University. World Conference on Technology, Innovation and Entrepreneurship. Procedia - Social and Behavioural Sciences, $195,925-931$.

Kaushal, U. (2016). Empowering engineering students through employability skills. Higher Learning Research Communications, 6(4).

Laguador J. M. (2013). Engineering students' academic and on-the-job training performance appraisal analysis. International Journal of e-Education, e-Business, e-Management and eLearning,

Vol. 3, No. 4.

Levenberg, A., \& Caspi, A. (2010). Comparing perceived formal and informal learning in face-to-face versus online environments. Interdisciplinary Journal of E-Learning and Learning Objects, Volume 6, 2010.

Lim, K. C., Idayu, N. M., Basri, R., Norhanim, A., Razak, \& Hamimi, O. (2016). Assessing students' knowledge and soft skills competency in the industrial training programme:

The employers' perspective. Review of European Studies, Vol. 8, No. 1.

Malloch, M., Cairns, L., Evan, K., \& O'Connor, B. N. (2011). Theories of work, place and learning: New directions. The Sage Handbook of Workplace Learning.

Marimuthu, M., Arokiasamy, L., \& Ismail, M. (2009). Human Capital Development and its impact on Firm Performance: Evidence from Developmental Economics. The Journal of International Social Research, 2(8).

MIDA (2010). Automotive Industry. Malaysian Industrial Development Authority Report. August 2010.

Muneer, S. \& Khairul, A. I. (2014). Challenges and opportunities for Malaysian automotive industry. American International Journal of Contemporary Research, Vol. 4, No. 9.

Nabila, Ab. M., \& Normah, O. (2012). UMP and DRB-HICOM: A mismatch of expectations. American Journal of Economics, June 2012, Special Issue: 22-25.

Ng, K. S., \& Nabila, A. (2012). Impact of motivation to learn on perceived training transfer: Empirical evidence from a bank. Proceedings of International Conference of Technology Management, Business and Entrepreneurship, Malaysia 18-19 Dec 2012.

Rahmah, I., Ishak, Y., \& Lai, W. S. (2011). Employers' perceptions on graduates in Malaysian services sector, Volume 5, Issue: 3. 184-193. 
Salleh M. S. \& Omar M. Z. (2012). University-Industry collaboration models in Malaysia. 6th International Forum on Engineering Education (IFEE 2012). Procedia - Social and Behavioural Sciences, 102(2013), $654-664$.

Tang, X. F. (2014). Engineering knowledge and student development: An institutional and pedagogical critique of engineering education. UMI. ProQuest.

Zaliza, H., \& Safarin, M. N. (2014). Unemployment among Malaysian graduates: Graduates' attributes, lecturers' competency and quality of education. 1056 - 1063. Elsevier Ltd.

Wenger, E. (1998). Communities of practice: Learning, meaning and identity. Cambridge, UK: Cambridge University Press. 